\author{
Albín Masarik \\ Matej Bel University, Faculty of Education, Banská Bystrica, Slovakia
}

\title{
A Depersonalised Object of Hope in a Funeral Sermon
}

\begin{abstract}
In this article, the author calls attention to a danger of proclaiming a depersonalised object of hope in a Christian funeral sermon, which he does not consider to be a legitimate Christian practice. The author reached this conclusion based on his analysis of one particular sermon from his research sample of $3 \times 50$ funeral sermons from three different church traditions (Lutheran church, evangelical churches, and Roman Catholic church). In the aforementioned funeral sermon, the object of hope was found to be articulated in a depersonalised form - the hope is not the eternity with the Lord, but simply: heaven. Christ is, in this particular sermon, merely a means by which the hearers may obtain their desired goal. Even though this funeral sermon was formulated using Christian terminology and was delivered by a Christian preacher, the author of this article does not regard its fundamental approach as Christian.
\end{abstract}

\section{Keywords}

Funeral sermon, hope, Christ, heaven.

\section{Introduction}

One of the generally accepted tasks of a funeral sermon is to comfort the bereaved. This is put forward by many authors of studies on occasional homiletics, but also by the preachers themselves in their funeral homilies. But as we were analysing the results of our empirical research into how the bereaved practicing 
Christians cope with grief, we were surprised that these grieving Christians did not include funeral sermon among their sources of help and comfort after the loss of their loved ones. ${ }^{1}$ For this reason, I decided to focus my subsequent research on tools by which a funeral sermon strives to fulfil this purpose. I dealt with the articulation of hope in Christ and, in doing so, I came across a funeral sermon, which highlights one of the risks of deformation of the Christian message. In this sermon, the preacher does not relate the hope to the person (of Christ) but to the "thing” (heaven). The fact that the deformation discovered in this sermon proved significant may also be regarded as beneficial for two reasons. Firstly, it helps us to recognise the problem as such. Moreover, recognising the problem may serve as a helpful impulse, such that we may strive to minimise its occurrence in our church life, even in its less expressive forms of presentation, or indeed in any form whereby the listener might mistakenly get under the impression that what Christianity offers is a "thing” rather than a relationship. I take this opportunity, therefore, to depict the finding of my research and to evaluate it from the perspective of Biblical adequacy.

\section{Way to finding}

On the basis of a research sample consisting of $3 \times 50$ funeral sermons $(50 \mathrm{Lu}-$ theran, 50 Evangelical, and 50 Roman Catholic), I investigated the manner in which they formulate the "hope in Christ". I put together this research sample with Michal Šalaga, ${ }^{2}$ who was, at the time, my doctoral student. The sample is comprised of published funeral sermons and is augmented by the funeral sermons that we received by request from various parish priests and pastors from a number of Slovak churches. We regard as the main advantage of our long-term work on the identical sample the assurance that results, which we shall

${ }^{1}$ See P. Dobríková, Sozial-kulturelle Aspekte in der Zeit des Sterbens und Trauerns in der römisch-katholischenund griechisch-katholischen Kirche in der Slowakei. Also: N. Kacianová, Die Pastoralpflege für die Leidtragenden in Evangelischer Kirche Augsburgischen Bekenntnisses in der Slowakei. And A. Masarik, Verstorbenentrauer unter Mitgliedern der Baptistengemeinden in der Slowakei. All of them in: P. Dobríková, W. Gebhardt, G. Giemza, V. Grajdian and A. Kacian (eds), Trauerbegleitung in unterschiedlichen kulturellen, sozialen und religiösen Kontexten, Dziegielów 2015, pp. 47-65; 115-133; 143-156.

${ }^{2}$ M. Šalaga used it in his dissertation, investigating the sermon's theological emphases. I used it in several studies and lectures on occasional homiletics presented for Christian ministers in Slovakia. 
reach, will provide a more complex picture of the phenomenon under scrutiny as well as its varied aspects, with which I deal in my research into occasional homiletics at our department.

\subsection{Biblical Text - Funeral Sermon - Approach and Depiction}

The aforementioned, very specifically developed, funeral sermon did not contribute to my earlier research in the course of which I noticed the present problem; I decided, however, to address these observations separately. We are dealing with an evangelical funeral sermon based on the passage from John 14:1-3 „In my Father's house there are many dwelling places..." The preacher treats the statement concerning dwelling places (heaven) as the kerygmatic emphasis of the passage and develops it further in a six-point structure: (1) Heaven is a prepared home. (2) Heaven is an eternal home. (3) Heaven is a happy home. (4) Heaven is an inhabited home. (5) Heavenly home is a longed-for home. (6) Heavenly home is a reachable home. The final point has a mission purpose. Nevertheless, the centre of the preacher's attention is not Christ, but heaven.

The entire sermon lost its orientation towards a relationship with Christ and rather emphasises a 'thing', which the grieving can obtain. At first, I designated this approach as 'product-oriented', wherein the orientation towards relationship is lost at the expense of the 'products', available to the listener. My colleague, Pavel Hanes, brought to my attention Jankélévitch's ${ }^{3}$ observation concerning a development in Judaism, which moved from personal expectation of the Messiah to the expectation of common good, which is no longer connected to his person. To capture this reality, Jankélévitch utilises the expression „depersonalised hope". After this discussion, I came to a conviction that, in the sermon under investigation, we may be dealing with a similar trend and thus Jankélévitch's term might also prove suitable as a descriptor for my observation. For this reason, I suggest that it be used in Christian homiletic to depict the negative phenomenon of the offer of good devoid of relationship, such that we may avoid it to the fullest extent possible.

\footnotetext{
${ }^{3} \mathrm{~V}$ Jankélévitch, L espérance et la fin des temps, in: La conscience juive face à l'histoire: le pardon. [Quatrième colloque des intellectuels juifs de langue française (octobre 1961)], (eds.), E.A. Levy-Valensi, J. Halperin, Paris 1965, p. 7-21, 21-28 (discussion); see p. 16-17.
} 


\subsection{A New Testament Critique of the Approach under Discussion}

The Christian funeral sermon under scrutiny offers 'good' (heaven) rather than following Christ, whose good gifts extend beyond the limits of the Christian's death. Upon a superficial look, such proclamation could seem like a legitimate part of the Christian existence: it uses the Bible, opens up Christian themes, utilises Christian terminology and is presented by a Christian minister. But in reality, this is not a Christian funeral sermon. It loses its real Christian focus by not calling the listener to following Christ, offering instead fulfilment of his or her (material) expectations, which are extended to the heavenly future. Our negative appraisal of this approach may be argued on several grounds: (a) relational emphasis of the sermon passage; (b) relational emphasis of the context; (c) Jesus' emphasis on the Great Commandment; (d) Paul's understanding of Christian preaching; (e) Paul's approach to comforting the grieving. In each case, we shall pursue our argument from specific example to general conclusions. The general conclusions shall be defined at two levels, at which we shall also suggest viable solutions: a) relationship to the Biblical text and b) relationship to the listener.

a) Relational emphasis of the sermon passage. The preacher's focus on "good" and the absence of a relationship with Christ does not correspond to the message of the chosen Biblical passage. The text from John 14:1-3, which serves as the point of departure for the sermon, is structured in a relational manner (Jesus - Father - you) and thus necessitates a relational interpretation. Jesus cares for his disciples, who are endangered by the imminent Easter (v. 1). He helps them by interpreting his departure as a voyage whose goal is to prepare a dwelling place for them (v. 2), which is followed, still within the framework of a relational structure, by v. 3: "And if I go and prepare a place for you, I will come again and will take you to myself, so that where I am, there you may be also."

The entire passage is saturated by Jesus' relationship to his disciples, his loving care for them, as well as his activity (I will prepare a place for you... I will take you to myself), which is oriented relationally (so that where I am, there you may be also). It is impossible, therefore, to pay attention solely to the "prepared dwelling place” (heaven) and overlook Christ. From this follows that this particular text can only be preached in such a way that emphasises its relational structure, from which stems the person-oriented hope.

${ }^{4} \mathrm{~J} 14,1-3$ in NRSV. 
In the present sermon, the preacher works with the biblical passage in such a manner as to ignore Jesus' emphasis on his relationship to the disciples. Thus, the only object of hope left is a depersonalised heaven. Besides, one may also observe a wrong approach to the relationship with the listener. What is really well captured are the listeners' expectations focussing on goodness and bliss, which they had already experienced in their current lives. But these expectations are being read into interpretation of the text and are objectivised in a heavenly dwelling. The opportunity to address the listener with the message about Christ, which goes beyond these expectations and which can truly fulfil them, is thus wasted. Thus, even though the text was selected very well, the fact that it was not interpreted relationally but materially impoverishes the listener and does not follow the authorial intent of the passage.

b) Even in the immediate context of the sermon text (John 14:6) ${ }^{5}$ Jesus stresses his importance for the possibility to „come to the Father", which excludes any notion of an effective mission without a relationship with Him.

This suggestion concerning a relationship with the text and the audience shows that the text invites the reader to grow in their relationship with the person of the Father, but the preacher's attention is diverted to an impersonal heaven. Such communication strategy could seem natural to those do not feel assurance in God, but in reality it does not bring them closer to God. So also, a person, who does have a sense of faith and hope in Christ, is not being built up and strengthen in their assurance on hearing this sermon.

c) The approach of the sermon is not in accord with Jesus' Great Commandment, which characterises Christianity as a positive relationship with God and a positive relationship with neighbour (Matt 22:34-40). Therefore, the proclamation of the Word in a funeral sermon must also be presented in relational rather than objectified terms.

It is precisely the funeral occasion, which gives meaning to such a context. When confronted with death, one is naturally inclined to emphasise relationships and, outside the everyday routine, the Great Commandment

5 The relational dimension is accented also by D. A. Carson by statement: „... he is going away to prepare a place for them, and he will come and get them so that they can be where he is. What more could they ask for?" D.A. Carson, The Gospel According to John, Leicester 1991, p. 381. 
makes better sense even to someone who otherwise does not follow it. At the same time, it must be interpreted as a secure hope to such a person whose life is formed by it.

d) The approach taken in the sermon does not correspond to Paul's understanding of Christian preaching as being focused on the crucified Christ, who is "the power of God and the wisdom of God” (1 Cor 1:24). This Pauline approach cannot be bypassed even in the case of a funeral sermon - provided that the preacher wants to offer his audience biblical help for their life after the loss of their loved one.

e) When the apostle Paul develops the theme of comforting the grieving (1 Thess 4:13-18), his entire statement is tied to Christ and His dealings with those who passed away as well as the bereaved, and is formulated emphasising verbs. For this reason, we may simply note that, in this biblical passage, Paul's understanding of comfort is expressed within a relational structure with the emphasis on what is expected to happen with the readers of 1 Thess, as they grow in their relationship with Christ.

Paul's approach is interesting in that, on the occasion of the loss of relationship with the temporally constrained human being, he points toward a relationship with the eternal God and, within this relationship, he also includes that relationship which was interrupted through death. In this manner, he very precisely addresses the needs of the grieving one as well as the seemingly egotistic logic of a bereaved person: „How will my life go on after this?" Paul shows to such a person that, after the period of confusion and seeking, there will come something which, due to its majestic glory, cannot even be described in human terms, such that he attempts only a brief description: "... together with them... we will be with the Lord forever." The relationship broken by death is addressed by a reference to the unbreakable relationship and communion, which involves both the one who grieves and the one who has passed away.

Based on the above, it seems that the funeral sermon under study constitutes a depersonalised, i.e. object-oriented, attempt at offering hope. This attempt is not coherent with the basic contours of a genuine Christian approach. It would be very well if we could conclude that the problem of depersonalised hope concerns only this sample, but opposite is, in fact, the case. This shortcoming may be found, in various degrees of intensity, also in sermons from other Christian traditions. On the basis of this preliminary finding, then, we may formulate the following working hypothesis: subsequent research into occasional homiletics 
will, in less expressive forms, keep finding depersonalised objects of eschatological hope with some regularity.

\section{The Way to Improvement and Necessary Qualities of Biblical Preaching at a Funeral Service}

The question why this phenomenon occurs in funeral sermons may be more exactly researched via interviews with preachers who wrote them. I suppose that, in this context, we could uncover problematic approaches to the biblical text on the one hand as well as to the listener on the other. I shall describe them under these two headings, along with suggestions for possible solutions.

In this regard, we may note a few basic requirements, which ought to be regarded as simultaneously applicable.

\subsection{Preacher's attitude to the biblical text.}

It is beneficial for a preacher to realise that, in this situation, a human being has nothing to say, ${ }^{6}$ because he or she possesses no means to resolve it. For this reason, one needs to open up to the transcendental Word, which entered our world precisely because of death (extent of sin). The preacher, who is cognisant of this, may select a kerygmatically effective text and may have something to do say at a funeral, because he or she proclaims hope in the person of Jesus Christ.

Problematic approach to the biblical text. ${ }^{7}$ In analysing funeral sermons, we encounter (1) inappropriately selected texts, ${ }^{8}$ which do not enable the listener

${ }^{6}$ J. Smolík, Radost ze slova, Prague 1983, p. 150: „In a funeral sermon, we proclaim a new reality, which Jesus Christ opened by his resurrection. We do so on the occasion of death, when one is at a loss of words."

${ }^{7}$ Among authors, who emphasise exegetical basis of a sermon, we find for instance Rudolf Bohren. He observes that occasional speeches are typically a form of violence inflicted upon a sermon passage. He asks whether the cause lies with inadequate exegesis or inappropriate selection of the sermon text. See R. Bohren, Predigtlehre, Munich 1980, p. 322. So also J. Smolík, Radost ze slova, Prague 1983, p. 151: „Various cases of abuse of biblical texts indicate that the preacher must exegetically work with texts used in funeral sermons and that he or she must have clarity in the biblical teaching concerning death. Reducing the funeral sermon to a 'religious speech' is all the more precarious, given that it takes place on the basis of a biblical passage, which is thus abused.'

${ }^{8}$ I have found sermons that were often based on an inappropriately limited passage, words taken out of context which the preachers gave an entirely different meaning, etc. When exegesis 
to see Jesus Christ as the source of hope, but rather serve to denote a homiletical situation; (2) funeral sermons that are based on an interpretation of text, which (even in the case of an appropriately selected text) does not make an effective use of the biblical message of hope in Jesus Christ.

Selection of the text - funeral sermons tend to be based on one specific, clearly delimitated biblical passage or on a handful of biblical promises, in which case the preacher works with one primary passage and several secondary passages. In both cases the preacher must take care to select a text, which first and foremost speaks about the hope in Christ and that in such a way that this message may be intertwined with the life of the deceased and his or her loved ones. ${ }^{9}$

Inappropriate selection of a biblical text makes it impossible to achieve that, which makes a Christian funeral valuable - to proclaim the hope in Jesus Christ. ${ }^{10}$ As noted above, a well-chosen text includes a clearly formulated message of hope in Christ, whose textual context relates to the situation of the deceased person (or the bereaved). But also in the case of suitable selection, we occasionally see that preachers only make use of the connection with the situation of the deceased, while variously reducing or deforming the hope in Christ.

\subsection{Preacher's attitude to the deceased}

Already in the selection of a biblical passage and in his work with it, the bereaved can recognise just how the preacher knew the deceased person. In objective cases where the preacher could not possibly know the deceased one, the selection indicates how important it is that the preacher pastorally communicate with

has been done inadequately, it is no wonder if the preacher places inadequate emphases in the sermon.

9 A nice example of such selection may be found in the Kiššs's collection of funeral sermons „Nádej nad hrobom“ (The hope on the grave), Bratislava 1995, in funeral sermon nr. 14. After the sudden death of a bus driver, Kišš chooses the biblical text based on the typical term for the deceased (way), but transforms it into a kerygmatic expression. Because of the idea of the journey to eternity, he chooses the text: J 14:4 "And you know the way to the place where I am going." This gives him the opportunity of a Christocentric proclamation.

${ }^{10}$ A fitting example of such an inappropriate selection may be found in a sermon delivered at the funeral of a murdered woman. I. Kiššs, Nádej nad hrobom, Bratislava 1995, selected the text "And there was night" (Joh 13:30) so as to express the darknenning of the murderer's mind. Although he related the text to the real life situation, he merely used the words of Scripture to communicate that he had nothing to say, instead of using the words of Scripture to proclaim hope in Jesus Christ. 
the family. It is the basic prerequisite for an effective proclamation of the hope in Christ into the family's specific situation.

If a funeral sermon is to have the expected quality, it must develop both of the aforementioned realities - the hope in Christ and the connection to the case. In order to nurture boldness, freshness and enthusiasm of the preacher for proclamation of Christ's death and resurrection at a funeral, it is useful to realise just how fascinating it was for Christ's contemporaries to listen the message of his death and resurrection. They were listening to a message about someone, who had died a violent death in a neighbouring city and whose grave was found empty on the third day, such that hundreds of people could testify that he was alive. His closest pupils interpreted his resurrection as a proof of the fact that his death was a ransom for the sins of humanity.

Because of several kinds of distance (historical, culture, etc.), this sense of fascination can be lost. In the New Testament, this hope is planted in various different contexts (historical: history of OT and NT; religious: Judaism, Gnosticism, etc.; existential: illness, riches and poverty, catastrophe, etc.). The preacher can get lost in these contexts if he or she highlights only the fact that people in the past, too, experienced pain or that Biblical contains metaphorical statements concerning death. Despite various forms of historical, cultural, and technological distance from the NT period, this message is still relevant (and unrivalled) answer to sin and death. It is very important, therefore, that the preacher work with this abundance of contexts in such a way as to enable the listeners to be similarly fascinated by the death and resurrection of Christ precisely when they need it so much - when they are bidding the last farewell to their beloved one. ${ }^{11}$ The diversion to "depersonalised hope" can thus never produce gain, but rather is bound to inflict a loss to the Christian proclamation at a funeral.

\subsection{Preacher's approach to listeners}

The preacher's approach to listeners may be helpful divided into approaches to practicing Christians, who are currently finding assurance of their faith in the death and resurrection of Jesus Christ, and to those, who follow current trends

11 E.g. Heb 12:22-24 would offer a unique context for processing anger and grief at the funeral of a murdered woman (see the previous note), esp. v. 24: „and to Jesus, the mediator of a new covenant, and to the sprinkled blood that speaks a better word than the blood of Abel." 
and come to the funeral with their joys and sorrows "of this world" without a functional connection between faith and their lives.

An effective way to avoid erroneous approaches to practicing believers requires the preacher to keep in mind that, even a believer's faith - however firm he or she may be in their personal assurance - may be shaken. The preacher reminds such a person what Jesus had said concerning death and resurrection. It is not a failure of Jesus' promises, but the very reason why he came to this world. Thus, the preacher leads the believer to interpret their situation of loss through the relationship to Christ, ${ }^{12}$ and thus find their peace in the fact that the deceased is with the Lord. The comfort does not mainly lie in the fact that we shall meet the deceased person in eternity. The hope does not lie in an understanding of eternity as an idealised form of bliss known on this earth, but in the relationship to Christ, who is so good and powerful that he can be trusted even when coming to terms with the shattering experience of death. In this context, the sermon ought to help the bereaved to come to accept his or her loss, i.e. to such an attitude that the deceased is with Christ and that is good (even while not regarding as good the fact that the person died).

Effective communication of gospel to the non-practicing people does not require that the preacher merely highlight how faith in Christ may fulfil their needs. We see this again in Jesus himself. The Jews were expecting a Messiah defined by their social, economic and political expectations. Jesus, however, showed them an entirely different dimension of the Kingdom of God. In this sense, the modern preacher faces a very similar audience, fill with expectations maximised by consumerism. In this position, he is moreover tempted like Jesus in the wilderness to show them how they can, through faith, fulfil their expectations. If the preacher gives in to take this approach, he or she cannot proclaim the hope in such a way that the people could obtain a lasting hope in Jesus; rather, they will be left with their own expectations, which can never (fulfilled or otherwise) fully comfort them. ${ }^{13}$ In a funeral sermon, the preacher has an op-

${ }^{12}$ For an interesting description of Christ-centred preaching, see T. Keller, Preaching. Communicating Faith in Age of Skepticism, New York 2015, p. 14: „Against all these rhetorical abuses Paul puts the message of "Christ and him crucified," but consider the meaning of this contrast. Paul indeed wants to reshape the foundations of listeners' hearts - he wants to change what they most fundamentally love, hope, and put their faith in."

${ }^{13}$ Joseph Ratzinger warns before similar emptying of the eschatological hope: The temptations of Jesus, as described in Matthew and Luke, express this expectation to perfection: bread from desert soil, sensational signs and wonders, assured political power over the entire 
portunity to surprise people by the hope in Jesus Christ, which has a genuine potential fulfil one's being and surmounts that which they have been expecting up to this point. Their hope is idealisation of the best they have experienced or negation of their sufferings, but then Christianity invites them to a relationship with the triune God, Creator, Comforter, and Saviour, thus offering them the content which is incomparably better than the best human-generated hopes. For this reason, the homiletical process suffers loss if a preacher does not talk about this relationship and instead presents depersonalised forms of hope, even if he might be doing it in an effort to make Christianity more attractive to a materialistically inclined listener.

Suggestions noted in this article may prove challenging to the preacher - with respect to both time and competence. The main objection against this suggestions may be that, in a parish with hundreds or even thousands of members, they are impossible to carry out. But the singularity of death and the singularity of hope in Christ require that the Christian preacher, along with his or her parish, recognise that the funeral service is one of their highest ministry priorities, such that they would together create favourable conditions for its realisation.

\section{Conclusion}

In this article, we have considered a funeral sermon taken from an ecumenically composed research sample of funeral sermons from Slovakia. This sermon has helped us, by its inappropriate selection of kerygmatic subjects, to identify a negative phenomenon, which I initially referred to as an object-oriented approach with absence of orientation to relationship. Upon discussing this matter with Pavel Hanes, my colleague, I realised that this phenomenon may be designated by a term borrowed from Vladimir Jankélévitch - „depersonalised hope" - who used it to describe a development in the history of Judaism. I regard this term as suitable to designate the currently discussed negative phenomenon in occasional homiletics.

world. The Messiah of the temptations in the sensational signs and wonders, assured political power over the entire world. The Messiah of the temptations in the wilderness - the Messiah of human expectation - is defined by his promises of consumer satisfaction and power over others. Anyone who thinks hard about this will realize that here „the Jews" represent humanity in general." J. Ratzinger, Eschatology, p. 61. 
The grieving, who are experiencing a relational loss when saying their last goodbye to the deceased cannot be comforted by a ,thing", even if it were heaven, resurrection or eternal life. Jesus expresses hope in relational terms (John 14:3, and will take you to myself, so that where I am, there you may be also") and the apostle Paul also sees the final hope in the fact that Christ's second coming will lead to the final state when „we will be with the Lord forever" (1 Thess 4:17). It is precisely this that ought to be object of comfort of grieving Christians and it is precisely in this manner that the hope ought to be presented in a relational connection to Christ. Thus, in those cases where we might observe a tendency to such a depersonalised form of hope, i.e. where one talks about positive effects of faith (e.g. resurrection, eternal life, etc.) without clearly expressed statements concerning the triune God (who has offered us a new life and to whom we shall give account of how we have lived), it is necessary to change our perspective. The minister may not presume that the listeners will have been practicing Christians with good catechetical education. More and more often it is a secularised person without active religious life and with no prerequisites for finding meaningful connections within the preacher's sermon on his or her own.

For this reason, it is necessary to develop a practical exegesis for the purposes of occasional homiletics in such a way that relationship may be accentuated and thus the listener confronted with the gospel. That is to say, the listener may thus see what Christ - crucified and risen - means for our own lives. Otherwise, there is a danger that, instead of making disciples for Christ, we shall multiply the numbers of those who want heaven but think that they do not need Christ.

\section{Bibliography}

Bohren R., Predigtlehre, München 1980.

Carson D., The Gospel According to John, Leicester 1991.

Dobríková P., Sozial-kulturelle Aspekte in der Zeit des Sterbens und Trauerns in der römisch-katholischen und griechisch-katholischen Kirche in der Slowakei, in: Trauerbegleitung in unterschiedlichen kulturellen, sozialen und religiösen Kontexten, (eds.) P. Dobríková, W. Gebhardt, G. Giemza, V. Grajdian and A. Kacian, Dziegielów 2015, pp. 47-65.

Jankélévitch V., L 'espérance et la fin des temps, In: La conscience juive face à l'histoire: le pardon. [Quatrième colloque des intellectuels juifs de langue française (octobre 1961)], (eds.), E.A. Levy-Valensi, J. Halperin, Paris 1965. 
Kacianová N., Die Pastoralpflege für die Leidtragenden in Evangelischer Kirche Augsburgischen Bekenntnisses in der Slowakei, in: Trauerbegleitung in unterschiedlichen kulturellen, sozialen und religiösen Kontexten. (eds.) P. Dobríková, W. Gebhardt, G. Giemza, V. Grajdian and A. Kacian (eds), Dziegielów 2015, pp. 115-133.

Keller T., Preaching. Communicating Faith in Age of Skepticism, New York 2015.

Kišš I., Nádej nad hrobom. Part 1.-4. Pohrebné kázne, Bratislava: self published, 1995-1996.

Masarik A., Analýza nekérygmatických komponentov pohrebných kázní prof. Igora Kišša. Banská Bystrica 2008.

Aby smútili s nádejou: vybrané aspekty pohrebných kázní, Brno 2011.

Verstorbenentrauer unter Mitgliedern der Baptistengemeinden in der Slowakei, in: Trauerbegleitung in unterschiedlichen kulturellen, sozialen und religiösen Kontexten, (eds.) P. Dobríková, W. Gebhardt, G. Giemza, V. Grajdian and A. Kacian, Dziegielów 2015, pp. 143-156.

Ratzinger J., Eschatology, Washington 2007.

Research sample of 3x50 funeral sermons of Slovak Christian ministers, archived at MBU, Faculty of Education, Department of Theology and Christian Education, Banská Bystrica, Slovakia.

Smolík J., Radost ze slova, Praha 1983.

Trauerbegleitung in unterschiedlichen kulturellen, sozialen und religiosen Kontexten., (eds.)

P. Dobríková, W. Gebhardt, G. Giemza, V. Grajdian, A. Kacian, Dziegielów 2015. 